\title{
OPTIMIZATION OF CARROT FERMENTATION CONDITIONS IN RICE BRAN BED USING LACTOBACILLUS PLANTARUM
}

\author{
Nguyen Minh Thuy ${ }^{1 凶}$, Ho Thi Ngan Ha ${ }^{1,2,3}$, Ngo Van Tai ${ }^{1}$ \\ ${ }^{1}$ Department of Food Technology, College of Agriculture, Can Tho University \\ 3/2 Str., Xuan Khanh Ward, Ninh Kieu District, Can Tho City, Vietnam \\ ${ }^{2}$ Faculty of Agriculture and Natural Resources, An Giang University \\ Long Xuyen City 90100, An Giang, Vietnam \\ ${ }^{3}$ Vietnam National University \\ Ho Chi Minh City, 900000, Vietnam
}

\begin{abstract}
Background. A statistical model was developed in this study to describe lactic acid production through a fermentation process of carrot in a rice bran bed by Lactobacillus plantarum.

Materials and methods. Response surface methodology (RSM) based on Box-Behnken design was employed to statistically evaluate and optimize the conditions for maximum lactic acid production.

Results. The significance and interaction of salt concentration, water and initial L. plantarum starter density on final lactic acid content were found. With the use of the developed quadratic model equation, a maximum achieved lactic acid content of $1.35 \%$ was obtained in a rice bran bed fermentation process at optimum operating conditions of approximately $2.95 \%$ salt, $48.24 \%$ water and $2.9 \log \mathrm{cfu} / \mathrm{g}$ of $L$. plantarum. After fermentation, the amount of total polyphenol content, antioxidant activity and carbohydrate had increased while the $\beta$-carotene in carrot was significantly retained (92.84\%).

Conclusion. The above results could provide a practical basis for the fermentation process in rice bran bed to produce a delicious and reliable product using L. plantarum strain XK 1.4 which could be a significant contribution to the food industry.
\end{abstract}

Keywords: rice bran, carrot, lactic acid, quality, optimization

\section{INTRODUCTION}

Vietnam is a large agricultural producer. This is important for the food supply in the country and the national economy. The Mekong Delta is considered the heart of the rice-producing regions in the country. As published by Statista Research Department (2021), in 2019 , approximately 43.45 million tons of paddy were produced in Vietnam. In an ideal rice milling process, this resulted from $8-12 \%$ bran depending on the milling degree. The rice bran obtained from the milling process is generally used for animal feeds. In recent years, the rice bran was used more for functional foods processing. This is due to the rice bran having high amounts of nutrients such as vitamins, minerals, fibers, lipid basically unsaturated fatty acids (Alauddina et al., 2017) and polyphenolic compounds. Rice bran has a shorter shelf-life due to an increase in free fatty lipids during storage. It can be used as a substrate for solid state fermentation which can increase the availability of nutrients and phytochemicals. Rice bran is also a good medium for vegetable fermentation (Ono 
et al., 2014) and this will be a promising alternative as a fermentation substrate.

Fermentation is one of the important food processing technologies (Hasan et al., 2014). Nukazuke is a type of Japanese preserved food made by fermenting vegetables in rice bran and which was developed in the $17^{\text {th }}$ century. A bed of rice bran as a main starting material was mixed with an appropriate amount of water and salt, and preferably with a high-quality starter which is fully fermented by the combination of lactic acid bacteria, yeast and fungus, used for pickling vegetables. Lactic acid fermentation of vegetables is a common practice which is carried out to preserve the nutritional and sensory characteristics of food products (Karovicova and Kohajdova, 2005). L. plantarum, L. pentosus, L. brevis, L. fermentum, L. casei are usually used in Asian fermented foods (Sajjad et al., 2020). Among them, L. plantarum has been the dominant microorganism isolated from most fermented vegetables (Molin et al., 2008). It was characterized by rapid production of lactic acid and tolerance to acidity (Thuy et al., 2017). According to statistics, the cultivation area of Vietnamese carrots is almost in the North of Vietnam. In the South of Vietnam, carrots are grown in Xuan Tho (Da Lat province) with a total cultivated area of about 240 ha/year. VietGAP standards are applied to the production to ensure products that are safe, high quality and have nice shape. Carrots are a source of antioxidants. Carotenoids, polyphenols and vitamins present in carrots act as antioxidants, anti-carcinogens and immune enhancers (Dias, 2014). Besides high amounts of $\beta$-carotene and other carotenoids, carrots contain vitamins $\mathrm{C}, \mathrm{K}$ and $\mathrm{B}$. Carrots are also a good source of dietary fiber and minerals (Dias, 2012). However, the consumer market for Vietnamese carrots is still unstable and plant-based products fermented by using rice bran are quite limited in Vietnam. Therefore, the study investigated the production of pickled carrots by fermentation of rice bran using L. plantarum under optimized conditions.

\section{MATERIALS AND METHODS}

\section{Sample preparation}

Vietnamese red carrots (Daucus carota) were obtained from Xuan Tho, Da Lat province, Vietnam. The carrots were washed with running water until the dirt is removed then drained and then peeled and cut, ready for the fermentation.

Rice bran was collected from Phuoc Thanh IV Trading-Production Company Limited, Vinh Long province, Vietnam. The samples were checked for their quality and microbiological suitability for human use based on Vietnamese Standard. The Rrice bran batch $(10 \mathrm{~kg})$ was roasted using a Roaster 106 (England) which controls the heating temperature of the air $\left(110^{\circ} \mathrm{C}\right.$ at $\left.10 \mathrm{mins}\right)$. After being processed, the heated rice bran was packed and contained in clear zippertop bags and properly labeled according to the type of bran and stored at $15 \pm 1{ }^{\circ} \mathrm{C}$ for further use.

Starter culture preparation. L. plantarum strain XK 1.4 which was isolated from cucumber showed the strongest antibacterial activity (Thuy et al., 2017). The culture was maintained at $-50^{\circ} \mathrm{C}$ in $20 \%$ glycerol stocks. For the purpose of usage, L. plantarum was proliferated in a liquid MRS medium until the density of the bacteria reached $5.0 \log \mathrm{cfu} / \mathrm{mL}$. This was counted as described by Hadioetomo (1993).

Preparation of fermented rice bran bed. The three essential ingredients were bran, salt and water. The water needs to be boiled and cooled before being added in order to remove the chlorine from the water. Vegetables [cabbage (3\%), garlic (2\%) and chili (2\%)] were added to make the rice bran bed tasty. These vegetables can also supplement nutrients, antiseptics, antioxidants as well as speed up the fermenting process and moderate moisture. All the ingredients were mixed. Once the basic mixture was created, it was inoculated with L. plantarum inoculants according to the experiment's design. The rectangle shaped plastic container (width: $18 \mathrm{~cm}$, height: $14 \mathrm{~cm}$ and length: $28 \mathrm{~cm}$ ) can be used for this purpose.

The process of carrot pickled in a salted rice bran bed. Carrot was prepared (peeled and cut) and carried out in the fermentation after the rice bran was roasted $\left(110^{\circ} \mathrm{C}\right.$ in 10 mins).

Prepare the roasted bran: A bed of rice-bran which was composed of rice-bran as the main starting material was mixed with an appropriate amount of water and salt as needed to achieve the right consistency. 
Thuy, N. M., Ha, H. T. N., Tai, N. V. (2021). Optimization of carrot fermentation conditions in rice bran bed using Lactobacillus plantarum. Acta Sci. Pol. Technol. Aliment., 20(4), 449-457. http://dx.doi.org/10.17306/J.AFS.2021.0944
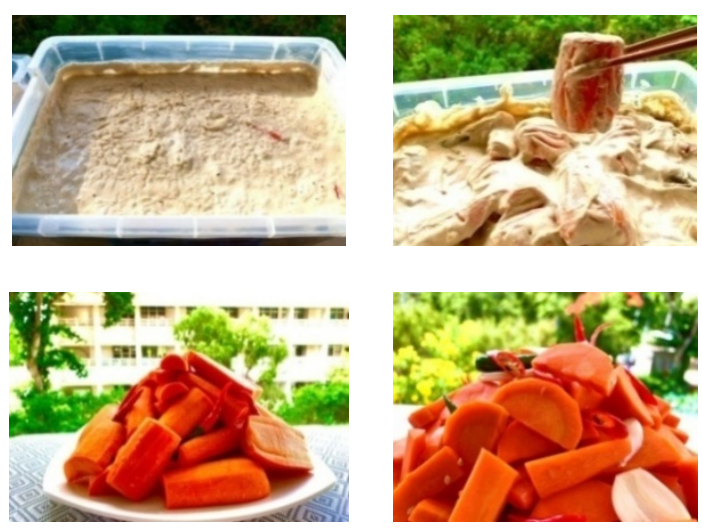

Fig. 1. Final product after two days of pickling

The Chinese cabbage, garlic and chili was added and placed deep in the bran bed which facilitates the growth of beneficial yeast and lactobacilli. Inoculated L. plantarum inoculants at different densities were added to the rice bran fermenting bed. The box was sealed and left at room temperature $\left(25 \pm 1^{\circ} \mathrm{C}\right)$ for 2 days. Push cut carrot completely inside the rice bran bed in a single layer after 2 days of rice bran bed preparation. Cover with the rice bran bed. Lightly press down on the top to ensure everything is packed in. Allow to sit for 2 days in a dry place. Be sure to stir the contents with clean hands at least once daily to ensure proper pickling and avoid sourness.

The fermentation process was conducted at room temperature $\left(25 \pm 1^{\circ} \mathrm{C}\right)$. After 2 days, the fermented odor of pickled carrot developed with a slightly sour one. The pickled carrot was taken out (Fig. 1) and then washed with potable water. The quality of the product was analyzed.

\section{Experimental design for optimization of lactic acid fermentation}

The optimization of the fermentation parameters was designed according to Response Surface Methodology (RSM) using Box-Behnken design (the STAGRAPHICS centurion software, version XV.I was used). A $3^{3}$ (salt concentration, water, L. plantarum) fractional factorial experimental design based on Box and Behnken (Myers and Montgomery, 2002) with six center runs was used, giving a total of 18 experimental runs.
Table 1. Experimental range and levels of the independent variables

\begin{tabular}{lrrc}
\hline \multirow{2}{*}{ Variables } & \multicolumn{3}{c}{ Coded levels } \\
\cline { 2 - 4 } & \multicolumn{1}{c}{-1} & 0 & 1 \\
\hline A: Salt concentration, \% w/v & 2.5 & 3 & 3.5 \\
B: Water, \% v/w & 46 & 48 & 50 \\
C: L. plantarum, $\log (\mathrm{cfu} / \mathrm{g})$ & 2 & 3 & 4 \\
\hline
\end{tabular}

Table 2. Experimental design used in RSM studies by using three independent variables with six center points (Box-Behnken design)

\begin{tabular}{crrrcrrr}
\hline Run order & $A$ & $B$ & $C$ & Run order & $A$ & $B$ & $C$ \\
\hline 1 & 0 & 0 & 0 & 10 & 0 & 0 & 0 \\
2 & 0 & -1 & -1 & 11 & 1 & 0 & 1 \\
3 & -1 & 0 & 1 & 12 & 0 & 0 & 0 \\
4 & -1 & -1 & 0 & 13 & -1 & 1 & 0 \\
5 & 0 & 0 & 0 & 14 & -1 & 0 & -1 \\
6 & 1 & 1 & 0 & 15 & 0 & -1 & 1 \\
7 & 1 & -1 & 0 & 16 & 0 & 1 & -1 \\
8 & 1 & 0 & -1 & 17 & 0 & 0 & 0 \\
9 & 0 & 0 & 0 & 18 & 0 & 1 & 1 \\
\hline
\end{tabular}

The dependent variable (responses) analyzed was lactic acid content of product. Each factor was surveyed with 3 levels, coded from $-1 ; 0 ;+1$. The level of encrypted variables and experimental layout are shown in Tables 1 and 2.

\section{Chemical characteristics analysis}

Determination of moisture content was carried out based on the Association of Official Analytical Chemists method (AOAC, 2005). Total acid (expressed as lactic acid) was determined by Valerio et al. (2008) method. Total phenolic compounds (TPC) were determined using a modified Folin-Ciocalteau colourimetric method (Wolfe et al., 2003). The $\beta$-carotene content was determined according to the method of Fikselová et al. (2008). Free radical scavenging 
activity (DPPH\%) of the carrot was followed and described by Liyana and Shahidi (2005).

Other nutrients analysis. The basic nutrients, protein, moisture and fat of rice bran were determined by using standard methods (AOAC, 2005). The total carbohydrate content was determined according to the method of McCseady (1970) and Dubois et al. (1956). Dietary fiber content was determined by an enzyme-gravimetric method (Prosky et al., 1988).

\section{Statistical analysis}

Statistical analysis was conducted for all the above determinations using a statistical program (ANOVA). Lactic acid was analysed by using the multiple regression analysis. A statistical analysis (STATGRAPHICS) was used to fit the model to the observed data. The proposed model (equation 1) for each response $(Y)$ was:

$$
\begin{aligned}
Y=b_{0} & +b_{1} A+b_{2} B+b_{3} C+b_{4} A B+b_{5} A C+ \\
& +b_{6} B C+b_{7} A^{2}+b_{8} B^{2}+b_{9} C^{2}
\end{aligned}
$$

where:

$A, B, C$ - independent variables,

$b_{0} \quad-$ offset term,

$b_{1}, b_{2}, b_{3}$ - linear effects,

$b_{4}, b_{5}, b_{6}-$ are interaction terms,

$b_{7}, b_{8}, b_{9}-$ squared effects.

The reference equation was selected to fit the data, based on the $R^{2}$ value obtained from the multiple regression. The selected reference equation should have a higher $R^{2}$ value.

\section{RESULTS AND DISCUSSION}

\section{The chemical compositions of rice bran and carrot}

Carrot. The chemical composition and radical scavenging capacity of carrot were presented in Table 3 . The moisture content of fresh carrot is about $87 \%$.
The bioactive compounds in carrot as $\beta$-carotene and total polyphenols content were $25.35 \pm 4.02 \mathrm{mg} \%$ and $17.59 \pm 3.43 \mathrm{mg} \mathrm{GAE} / 100 \mathrm{~g}$, respectively. The obtained data was considerably lower than the findings of Sharma et al. (2012) and Leja et al. (2013) who reported that the $\beta$-carotene and polyphenol content of carrot ranged $39.6 \pm 0.81 \mathrm{mg} / 100 \mathrm{~g}$ and $18.7 \pm 1.2$ to $58.6 \pm 2.6 \mathrm{mg} / 100 \mathrm{~g}$ fresh weight, respectively. However, Bystrická et al. (2015) determined a lower content of $\beta$-carotene and polyphenols in carrot (Daucus carota L. ssp. sativus (Hoffm.) Arcang.) in comparison with our results, in which the $\beta$-carotenes ranged from $24.58 \pm 2.38 \mathrm{mg} / \mathrm{kg}$ to $124.28 \pm 3.54 \mathrm{mg} / \mathrm{kg}$ and total polyphenols content in carrot samples ranged from $81.25 \pm 13.11 \mathrm{mg} / \mathrm{kg}$ to $113.69 \pm 11.57 \mathrm{mg} / \mathrm{kg}$. The various growing locations and the variety influenced the carotenoid contents of carrots (Kidmose et al., 2006).

Carrot is an excellent source of $\beta$-carotene, a precursor of vitamin $\mathrm{A}$, and has a high total polyphenol content which neutralizes the effect of free radicals. Radical scavenging capacity of $\mathrm{DPPH} \%$ is widely used to evaluate the antioxidant activity of food (Lee et al., 2007). The result of the scavenging activity in carrot was found to be $59.07 \pm 0.40 \%$. Yen et al. (2008) observed very high DPPH neutralization activity $(80$ $90 \%$ ) in red carrot roots. Ebadollahi-Natanzi and Arab-Rahmatipour (2014) have also studied the free radical scavenging activity of carrot (Daucus carota L.) grown in three different regions of Iran. It was observed that the highest and lowest antioxidant activities were found to be $47.20 \pm 10.42$ and $263.86 \pm 39.53 \% \mathrm{DPPH}$ which were similar to those of carrots taken from the Zarinshahr and Andimeshk regions in Isfahan and Khuzestan provinces, respectively. The fiber content of carrot was evaluated at $2.25 \pm 0.25 \%$. Dietary fibers are not only desirable for their nutritional properties but also for their functional and technological properties (Schieber et al., 2001). The carbohydrate content in fresh carrot was quite high $(9.55 \pm 0.51 \%)$ and it is

Table 3. Chemical compositions of carrot and radical scavenging capacity of DPPH

\begin{tabular}{cccccc}
\hline $\begin{array}{c}\text { Moisture content } \\
\%\end{array}$ & $\begin{array}{c}\text { Carbohydrate } \\
\%\end{array}$ & $\begin{array}{c}\beta \text {-carotene } \\
\mathrm{mg} \%\end{array}$ & $\begin{array}{c}\text { Total polyphenol } \\
\mathrm{mg} \mathrm{GAE} / 100 \mathrm{~g}\end{array}$ & $\begin{array}{c}\text { Fiber content } \\
\%\end{array}$ & $\begin{array}{c}\text { DPPH } \\
\%\end{array}$ \\
\hline $86.67 \pm 1.15$ & $9.55 \pm 0.51$ & $25.35 \pm 4.02$ & $17.59 \pm 3.43$ & $2.25 \pm 0.25$ \\
\hline
\end{tabular}

Values are mean \pm STD of three replicates. 
Thuy, N. M., Ha, H. T. N., Tai, N. V. (2021). Optimization of carrot fermentation conditions in rice bran bed using Lactobacillus plantarum. Acta Sci. Pol. Technol. Aliment., 20(4), 449-457. http://dx.doi.org/10.17306/J.AFS.2021.0944

Table 4. Chemical compositions of white rice bran, $\%$

\begin{tabular}{ccccc}
\hline Moisture content & Carbohydrate content & Protein content & Lipid content & Fiber content \\
\hline $11.70^{*} \pm 0.07$ & $53.74 \pm 0.74$ & $11.42 \pm 0.27$ & $14.39 \pm 0.024$ & $4.66 \pm 0.05$ \\
\hline
\end{tabular}

*Values are mean $\pm \mathrm{STD}$ of three replicates.

also a good source of nutrients for carrot fermentation. Carrot represents a potential source of nutrients and bioactive compounds and it was useful for the preparation of valuable food supplements.

Rice bran. The analysis results of the chemical composition of rice bran were shown in Table 4. The analysis results showed that the moisture content of white rice bran is about $11.70 \%$. This obtained result was similar to the research results of Lien and Thuy (2016) and Hettiarachchy (2009) with the value of white milled rice bran being $11.9 \%$ and the defatted bran about $10.5-12.0 \%$, respectively. The carbohydrate content of white bran was about $53.74 \%$ - slightly higher than the result of Hernandez et al. (2000) with a value of $48.3 \%$. In contrast, the protein content of bran was about $11.42 \%$ - lower than the protein content in the study of Hernandez et al. (2000) with a value of $13.4 \%$. The rice bran contained about $14.39 \%$ lipid, which was almost similar to the research results of Cheruvanky (2003) in which the proposed fat content in rice bran was about $15-20 \%$. The differences in the milling process greatly affect the chemical composition of rice bran. Bergman (2019) also posted that geographical conditions and rice varieties also significantly affected the quality of bran. The bran can be oxidized due to lipase. Heat treatment $\left(110^{\circ} \mathrm{C}\right.$ in 10 minutes) is also a way that effectively inhibits the activity of this enzyme. Besides that, with high sugar and low lipid content, the white bran was appropiately chosen to prepare a pickling bed for vegetable fermentation.

\section{Optimization of final lactic acid content of product by RSM}

RSM was used to optimize the fermentation process design factors (independent variables). Using the results of the experiments the following second order polynomial equation giving the lactic acid content as a function of salt concentration $(A, \% \mathrm{w} / \mathrm{v})$, water $(B$,
$\% \mathrm{v} / \mathrm{w})$ and $L$. plantarum density $[C, \log (\mathrm{cfu} / \mathrm{g})]$ was obtained (equation 2). The validity of the fitted model was evaluated, and its statistical significance was controlled by $F$-test. The analysis of variance (ANOVA) for the response surface full quadratic model is given.

$$
\begin{aligned}
& \text { Lactic acid content, } \%=-72.37+0.626 A+ \\
& +2.965 B+0.878 C-0.288 A^{2}+0.025 A B- \\
& -0.037 A C-0.031 B^{2}-0.007 B C-0.074 C^{2}
\end{aligned}
$$

It can be indicated that the model is highly statistically significant at $95 \%$ confidence level, with $F$-ratio of 24.8 , and very low probability value. The coefficient of determination $\left(R^{2}\right.$ is 0.8353$)$ implies that the sample variation of $83.53 \%$ for lactic acid content is attributed to the independent variables. The value of the adjusted determination coefficient is also very high to indicate a high significance of the model. In addition, the lack of fit test was performed by comparing the variability of the current model residuals to the variability between observations at replicate settings of the factors. Since the $P$-value for lack-of-fit (0.058) in the ANOVA table is greater to 0.05 , the model appears to be adequate for the observed data at the $95.0 \%$ confidence level. A Pareto chart was used in this work to make it much easier to visualize the main and interaction effects of all factors regarding the lactic acid content of the product after fermenting (Fig. 2).

The initial water concentration and the interactive effect of salt concentration and water have a significant positive impact on lactic acid content, while the initial salt concentration, initial bacteria density and the interaction of salt and initial bacteria density, as well as the interactice of salt and water concentration, seem to have a negative impact on lactic acid content. Thus, the achieved lactic acid content of pickled carrot decreases with an increase of the initial salt. The amount of starter culture had a significant influence on the final acid content and the sensory quality of the product.

The higher sourness and acidic odor were observed in the pickled vegetables with higher starter's addition. 
Thuy, N. M., Ha, H. T. N., Tai, N. V. (2021). Optimization of carrot fermentation conditions in rice bran bed using Lactobacillus plantarum. Acta Sci. Pol. Technol. Aliment., 20(4), 449-457. http://dx.doi.org/10.17306/J.AFS.2021.0944

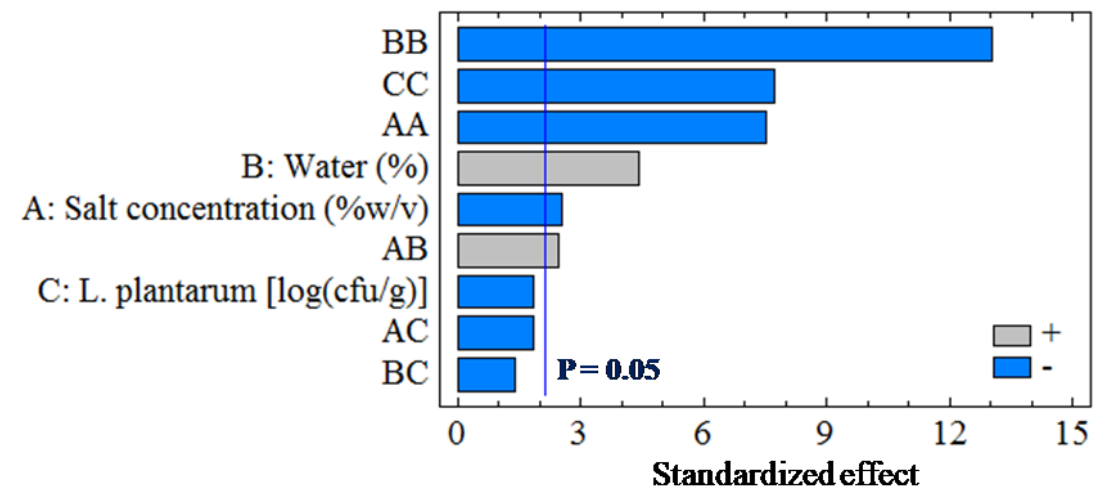

Fig. 2. Pareto chart showing the effects of different independent variables on lactic acid content of pickled carrot. The model identified that within the range of experiments, the quadratic effect of water, salt concentration and bacteria density has a highly significant negative influence on the lactic acid content

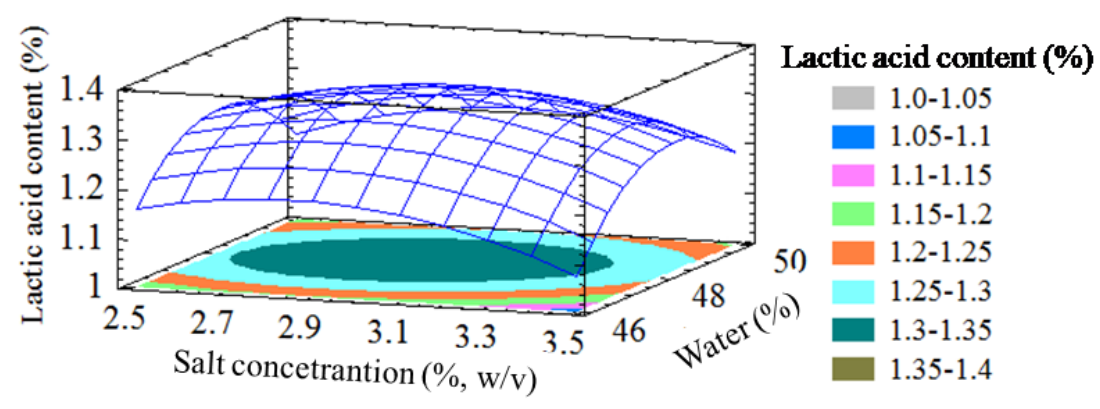

Fig. 3. Response surface and contour plot of salt concentration versus water content on lactic acid production (initial L. plantarum density was kept constant at $3 \log \mathrm{cfu} / \mathrm{g})$

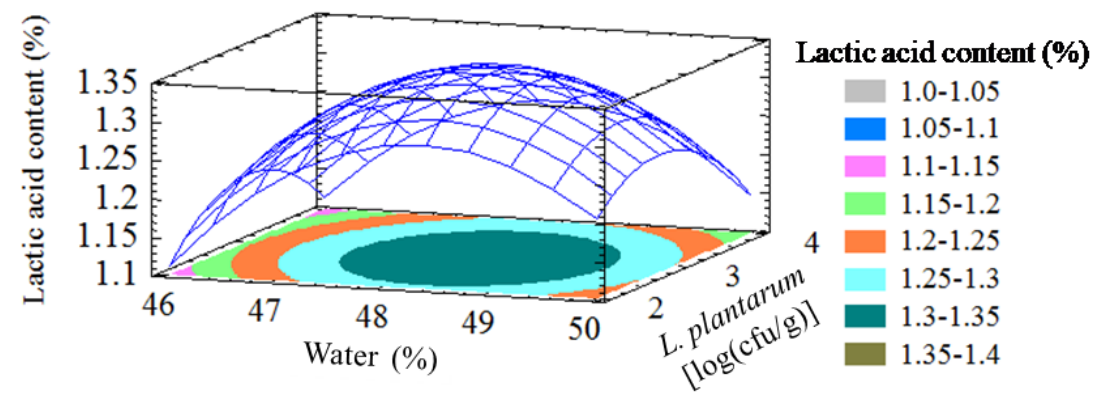

Fig. 4. Response surface and contour plot of water content versus initial L. plantarum density on lactic acid production (initial salt concentration was kept at $3 \%$ ) 


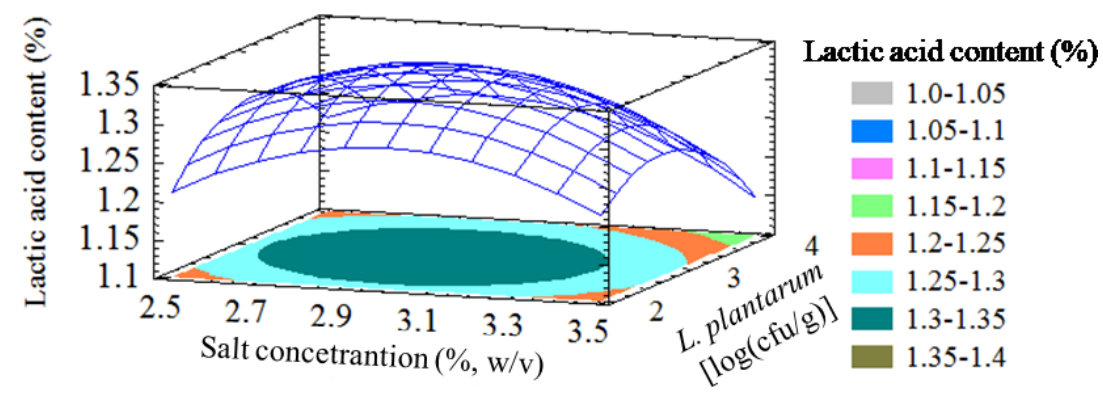

Fig. 5. Response surface and contour plot of salt concentration versus initial L. plantarum density on lactic acid production (initial water content was kept at $48 \%$ )

Brining is also an important step in vegetable fermentation. The lactic acid contents were achieved higher when 2 to $3 \%$ salt levels were used and lower when $4 \%$ salt was used. At higher salt concentrations, lactic fermentation seemed to be decreased. The typical salt concentrations added to cabbage for sauerkraut fermentation can range between 2 to $10 \%(\mathrm{w} / \mathrm{w})$ (Xiong et al., 2016). LAB can tolerate high salt concentrations. This salt tolerance gives them an advantage over less tolerant species and allows lactic acid fermentation that inhibits the growth of non-desirable organisms (Rao et al., 2004).

During vegetable fermentation, the $2-5 \%$ brine solutions are added to provide hypertonic conditions that inhibit the formation of spoilage-causing organisms during and after the fermentation process. Figures 3 to 5 represent the response contour and surface plots for the optimization of fermentation conditions of lactic acid production. The maximum obtained lactic acid of $1.35 \%$ appeared at initial salt concentration, water content and L. plantarum density of $2.95 \%, 48.24 \%$ and $2.9 \log \mathrm{cfu} / \mathrm{g}$, respectively.

\section{The nutrients and bioactive compounds in pickled carrot}

This study (Table 5) also confirms that the amount of $\beta$-carotene in carrot is significantly retained even after fermentation (92.84\%). Panda et al. (2007) reported that $\beta$-carotene remained more or less the same after fermentation, i.e., no significant difference was reported. In the opposite trend, the carbohydrate content was slightly increased $(+4.88 \%)$ after fermentation.

It can be explained by the influence of the osmosis process between the material and rice bran bed. The total polyphenol content and antioxidant activity were also increased after fermentation $(+10.57 \%$ and $+4.79 \%$, respectively). During fermentation, the rice brand bed was added with Chinese cabbage, garlic, and chili which are good sources of antioxidant compounds (Dieu and Thuy, 2016; Ku et al., 2019). The influence of the osmotic process between material and rice bran bed could lead to an increase in the polyphenol content of the product. The fiber content of the product was not significantly different in comparison with raw material. From the above investigation,

Table 5. The comparison of raw carrot and pickled carrot in rice bran bed

\begin{tabular}{lccc}
\hline \multicolumn{1}{c}{ Nutrients } & Raw carrot & Pickled carrot & Remark, \% \\
\hline$\beta$-carotene, $\mathrm{mg} \%$ & $25.35 \pm 1.02$ & $23.53 \pm 0.34$ & -7.16 \\
Total polyphenol, \% & $17.59 \pm 1.43$ & $19.45 \pm 0.34$ & +10.57 \\
Carbohydrate, \% & $9.55 \pm 0.051$ & $10.04 \pm 0.022$ & +4.88 \\
Fiber content, \% & $2.25 \pm 0.25$ & $2.24 \pm 0.11$ & not significant \\
DPPH, \% & $59.07 \pm 0.40$ & $62.04 \pm 0.53$ & +4.79 \\
\hline
\end{tabular}


the Vietnamese carrot picked in a salted rice-bran bed had a bright color, delicious flavor, crunchy structure and high nutritional values.

\section{CONCLUSION}

RSM and Box-Behnken design proved to be a reliable and powerful tool for modelling, optimizing and studying the interactive effects of three process variables (salt concentration, water and density of $L$. plantarum) of lactic acid production from fermentation of carrot in rice bran bed. A highly significant $\left(R^{2}=83.53 \%\right)$ regression quadratic model equation was obtained by analyzing the experimental data. The maximum predicted final lactic acid content of pickled carrot is $1.35 \%$.

\section{REFERENCES}

Alauddina, A., Islama, J., Shirakawaa, H., Koseki, T., Ardiansyah, A., Komai, M. (2017). Rice bran as a functional food: An overview of the conversion of rice bran into a superfood/functional food (chapter 14). In M. Alauddina, J. Islama, H. Shirakawaa, T. Kosekib, A. M. Komaia (Eds.), Superfood and functional food - An overview of their processing and utilization. IntechOpen, https://doi. org/10.5772/66298

AOAC (2005). Official methods of analysis. Washington, DC: Association of Official Analytical Chemists.

Bergman, C. J. (2019). Rice end-use quality analysis. In J. Bao (Ed.), Rice (pp. 273-337). AACC International Press. https://doi.org/10.1016/B978-0-12-8115084.00009-5

Bystrická, J., Kavalcová, P., Musilová, J., Vollmannová, A., Tóth, T., Lenková, M. (2015). Carrot (Daucus carota L. ssp. sativus (Hoffm.) Arcang.) as source of antioxidants. Acta Agr. Slov., 105(2), 303-311. https://doi. org/10.14720/aas.2015.105.2.13

Cheruvanky, R. (2003). Phytochemical products: rice bran. In I. Johnson, G. Williamson (Eds.), Phytochemical functional foods (pp. 347-376). Woodhead Publishing. https://doi.org/10.1533/9781855736986.2.347

Dias, J. C. (2014). Nutritional and health benefits of carrots and their seed extracts. Food Nutr. Sci., 5, 2147-2156. https://doi.org/10.4236/fns.2014.522227

Dias, J. S. (2012). Nutritional quality and health benefits of vegetables: A review. Food Nutr. Sci., 3, 1354-1374. https://doi.org/10.4236/fns.2012.310179
Dieu, V. T., Thuy, N. M. (2016). The bioactive compounds, free radical scavenging activity and sensory qualities of garlic (Allium sativum) as affected by temperature and time. Can Tho Unin. J. Sci., Agric., 1, 131-139.

Dubois, M., Gilles, K. A., Hamilton, J. K., Rebers, P. T., Smith, F. (1956). Colorimetric method for determination of sugars and related substances. Anal. Chem., 28(3), 350-356. https://doi.org/10.1021/ac60111a017

Ebadollahi-Natanzi, A., Arab-Rahmatipour, G. (2014). Study on free radical scavenging activity of carrot (Daucus carota L.) grown in three different regions of Iran. J. Chem. Pharm. Res., 6(11), 268-274.

Fikselová, M., Šilhár, S., Mareček, J., Frančáková, H. (2008). Extraction of carrot (Daucus carota L.) carotenes under different conditions. Czech J. Food Sci., 26, 268-274. https://doi.org/10.17221/9/2008-CJFS

Hadioetomo, R. S. (1993). Mikrobiologi Dasar dalam Praktek [Basic microbiology in practice]. Jakarta: Gramedia Pustaka Utama.

Hasan, M. N., Sultan, M. Z., Mar-E-Um, M. (2014). Significance of fermented food in nutrition and food science. J. Sci. Res., 6(2), 373-386. http://doi.org/10.3329/JSR. V6I2.16530

Hernandez, N., Rodriguez-Alegria, M. E., Gonzalez, F., Lopez-Munguia, A. (2000). Enzymatic treatment of rice bran to improve processing. J. Am. Oil Chem. Soc., 77(2), 177-180. https://doi.org/10.1007/s11746-000-0028-2

Hettiarachchy, N., Kannan, A., Horax, R. (2009). The unique nutritional. Nutraceutical properties of rice protein. In Rice utilization workshop. USA Rice Federation.

Karovicova, J., Kohajdova, Z. (2005). Lactic acid-fermented vegetable juices-palatabl and wholesome foods. Chem. Pap., 59, 143-148.

Kidmose, U., Hansen, S. L., Christensen, L. P., Edelenbos, Larsen, E., Nørbæk, R. (2006). Effects of genotype, root size, storage, and processing on bioactive compounds in organically grown carrots (Daucus carota L.). J. Food Sci., 69, 388-394.

Ku, Y. G., Kim, H. C., Bae, J. H., Kang, B. S., Nemirovski, A., Barasch, D., Gorinstein, S. (2019). Antioxidant capacities and polyphenols in autumn-growing cultivar of Chinese cabbage (Brassica rapa L. ssp. pekinensis cv. Bulam Plus). Eur. Food Res. Technol., 245(9), 18711879. https://doi.org/10.1007/s00217-019-03294-0

Lee, B. B., Cha, M. R., Kim, S. Y., Park, E., Park, H. M., Lee, S. C. (2007). Antioxidative and anticancer activity of extracts of cherry (Prunus serratula var. spontanea) blossoms. Plant Food Hum. Nutr., 62, 79-84. https://doi. org/10.1007/s11130-007-0045-9 
Thuy, N. M., Ha, H. T. N., Tai, N. V. (2021). Optimization of carrot fermentation conditions in rice bran bed using Lactobacillus plantarum. Acta Sci. Pol. Technol. Aliment., 20(4), 449-457. http://dx.doi.org/10.17306/J.AFS.2021.0944

Leja, M., Kamińska, I., Kramer, M., Maksylewicz-Kaul, A., Kammerer, D., Carle, R., Baranski, R. (2013). The content of phenolic compounds and radical scavenging activity varies with carrot origin and root color. Plant Foods Hum. Nutr., 68(2), 163-170. http://doi. org/10.1007/s11130-013-0351-3

Lien, T. N., Thuy, N. M. (2016). Production glucose solution from rice (IR5451) bran by enzymatic hydrolysis. Can Tho Uni. J. Sci., 1, 113-121.

Liyana, P. C. M., Shahidi, F. (2005). Antioxidant activity of commercial soft and hard wheat (Triticum aestivum L.) as affected by gastric $\mathrm{pH}$ conditions. J. Agric. Food Chem., 53(7), 2433-2440. https://doi.org/10.1021/jf049320i

McCseady, R. M. (1970). Determination of starch and dextrin in methods of food analysis (2nd ed.). London, UK: Academic Press.

Molin, G. Sauerkraut, Holzapfel, W., Schillinger, U., Buckenhüskes, H. (2008). Lactobacillus plantarum: The role in foods and in human health. In E. R. (Ted) Farnworth (Ed.), Handbook of fermented functional foods. New York: CRC Press.

Myers, R. H., Montgomery, D. C. (2002). Response surface methodology: Product and process optimization using designed experiments (2nd ed.). New York: John Wiley.

Ono, H., Nishio, S., Tsurii, J., Kawamoto, T., Sonomoto, K., Nakayama, J. (2014). Monitoring of the microbiota profile in nukadoko, a naturally fermented rice bran bed for pickling vegetables. J. Biosci. Bioeng., 118(5), 520 525. https://doi.org/10.1016/j.jbiosc.2014.04.017

Panda, S. H., Parmanick, M., Ray, R. C. (2007). Lactic acid fermentation of sweet potato (Ipomoea batatas L.) into pickles. J. Food Proces. Preser., 31(1), 83-101. https:// doi.org/10.1111/j.1745-4549.2007.00110.x

Prosky, L., Asp, N. G., Schweizer, T. F., Devries, J. W., Furda, I. (1998). Determination of insoluble, soluble, and total dietary fiber in foods and food products: Interlaboratory study. J. Assoc. Off. Anal. Chem., 71(5), 1017-1023. https://doi.org/10.1093/jaoac/71.5.1017
Rao, M. S., Pintado, J., Stevens, W. F., Guyot, J. P. (2004). Kinetic growth parameters of different amylolytic and non-amylolytic Lactobacillus strains under various salt and $\mathrm{pH}$ conditions. Biores. Technol., 94(3), 331-337. https://doi.org/10.1016/j.biortech.2003.11.028

Sajjad, N., Rasool, A., Fazili, A. B. A., Eijaz Ahmed Bhat, E. A. (2020). Fermentation of fruits and vegetables. Plant Arch., 20, Suppl. 2, 1338-1342.

Schieber, A., Stintzing, F. C., Carle, R. (2001). By-products of plant food processing as a source of functional compounds - recent developments. Trends Food Sci. Technol., 12, 11, 401-413. https://doi.org/10.1016/ S0924-2244(02)00012-2

Sharma, K. D., Karki, S., Thakur, N. S., Attri, S. (2012). Chemical composition, functional properties and processing of carrot - A review. J. Food Sci. Technol., 49(1), 22-32. https://doi.org/10.1007/s13197-011-0310-7

Thuy, N. M., Cuong, N. X., Thanh, N. V., Tuyen, N. T. M. (2017). Characterization of lactic acid bacteria isolated from pickled vegetables as potential starters for yogurt preparation. Can Tho Univ. J. Sci., 6, 111-120. https:// doi.org/10.22144/ctu.jen.2017.034

Valerio, F., De Bellis, P., Lonigro, S. L., Visconti, A., Lavermicocca, P. (2008). Use of Lactobacillus plantarum fermentation products in bread-making to prevent Bacillus subtilis ropy spoilage. Inter. J. Food Microbiol., 122(3), 328-332.

Wolfe, K., Wu, X., Liu, R. H. (2003). Antioxidant activity of apple peels. J. Agric. Food Chem., 51(3), 609-614. https://doi.org/10.1021/jf020782a

Xiong, T., Li, J., Liang, F., Wang, Y., Guan, Q., Xie, M. (2016). Effects of salt concentration on Chinese sauerkraut fermentation. LWT - Food Sci. Technol., 69, 169174. https://doi.org/10.1016/j.lwt.2015.12.057

Yen, Y. H., Shih, C. H., Chang, C. H. (2008). Effect of adding ascorbic acid and glucose on the antioxidative properties during storage of dried carrot. Food Chem., 107, 1, 265272. https://doi.org/10.1016/j.foodchem.2007.08.013 